$\mathrm{JD}$

78,7

42

Received 4 February 2021

Revised 30 April 2021 Accepted 1 May 2021

\section{"Let's keep this video as real as possible": young video bloggers constructing cognitive authority through a health-related information creation process}

\author{
Anna-Maija Multas and Noora Hirvonen \\ Information Studies, Faculty of Humanities, University of Oulu, Oulu, Finland
}

\begin{abstract}
Purpose - This study examines the information literacy practices of young video bloggers, focusing on the ways in which they construct their cognitive authority through a health-related information creation process. Design/methodology/approach - This study draws upon socially oriented information literacy research and nexus analysis as its methodological framework. Data, including YouTube videos, theme interviews and video diaries, were collected with three Finnish video bloggers and qualitatively analysed using nexus analytical concepts to describe the central elements of social action.

Findings - The study shows that video bloggers employ several information practices during the information creation process, including planning, information-seeking, organization, editing and presentation of information. They construct their cognitive authority in relation to their anticipated audience by grounding it on different types of information: experience-based, embodied and scientific. Trustworthiness, emphasized with authenticity and genuineness, and competence, based on experience, expertise and second-hand information, were recognized as key components of credibility in this context.

Originality/value - This study increases the understanding of the complex ways in which young people create information on social media and influence their audiences. The study contributes to information literacy research by offering insights into the under-researched area of information creation. It is among the few studies to examine cognitive authority construction in the information creation process. The notion of authority as constructed through trustworthiness and competence and grounded on different types of information, can be taken into account in practice by information professionals and educators when planning information literacy instruction.
\end{abstract}

Keywords Cognitive authority, Information literacy, Information creation, Nexus analysis, Video blogging, YouTube

Paper type Research paper

\section{Introduction}

YouTube, a video sharing service founded in 2005, has become the most popular online platform among young people all over the world (see, e.g. Anderson and Jiang, 2018). It has over 2 billion users, most of whom are between 18 and 34 years old (YouTube, 2021). Through YouTube, users can upload and view videos; rate, share, report or comment on videos; and

(C) Anna-Maija Multas and Noora Hirvonen. Published by Emerald Publishing Limited. This article is published under the Creative Commons Attribution (CC BY 4.0) licence. Anyone may reproduce, distribute, translate and create derivative works of this article (for both commercial and non-commercial purposes), subject to full attribution to the original publication and authors. The full terms of this licence may be seen at http://creativecommons.org/licences/by/4.0/legalcode

The authors would like to acknowledge the financial support provided by the Eudaimonia doctoral programme, the Academy of Finland (Grant No. 299112) and The University of Oulu Scholarship Foundation. They also thank Professor Maija-Leena Huotari for her valuable comments regarding this article and all the participants for their contributions. 
subscribe to other users' channels. According to the Pew Research Center, in January 2019, nearly 44,000 YouTube channels had at least 250,000 subscribers (van Kessel et al., 2019). These channels collectively produced approximately $48,000 \mathrm{~h}$ of content, mainly in languages other than English (van Kessel et al., 2019). This study concerns the video production practice (Balleys et al., 2020) of video blogging, or vlogging. A vlog can be defined as "a video in which the author(s) express thoughts or opinions on their daily experiences and concerns through the use of the first-person point of view" (Balleys et al., 2020).

As young people are increasingly turning to social media to find information, such as news (Purdue, 2019) or health-related information (Swist et al., 2015; Wartella et al., 2016), social media influencers, such as video bloggers, may act as new types of authoritative voices for young people regarding health issues (see, e.g. Balabanis and Chatzopoulou, 2019; Coates et al., 2019). This became evident in Finland during the COVID-19 pandemic in spring 2020, when the government recruited social media influencers to spread timely and accurate information about the coronavirus (Ping Helsinki, 2020). According to Ping Helsinki (2020), the campaign reached over 4 million people, half of whom expressed that it had an influence on how they behaved during the pandemic.

In addition to offering young people a platform on which to connect, find and share information, social media provides opportunities to influence other peoples' social lives (see, e.g. Huang et al., 2014). For example, YouTube videos may serve as a social recognition process, enabling young video producers and viewers to recognize themselves in others (Balleys et al., 2020). However, there are indications that social media content that displays risky health behaviour, particularly drinking or smoking, may have an effect on young people's health behaviours (see, e.g. Goodyear et al., 2019; Huang et al., 2014; Vaterlaus et al., 2014). Moreover, researchers have expressed concerns that young people have difficulties to assess the credibility of information (Hargittai et al., 2010; Subramaniam et al., 2015; Nygren and Guath, 2019) or the authority of online sources (Hirvonen and Palmgren-Neuvonen, 2019), which might make them vulnerable to misleading or harmful information (Cusack et al., 2017).

As such, it is vital for the viewers and producers of health-related content on social media to exercise critical thinking in order to mitigate the effects of information overload and handle the variety of information, including misinformation, on the web (Koltay, 2017). The Association of College and Research Libraries (2016) emphasizes information-seeking and evaluation, information creation and recognition of authoritative voices as core competencies in their Framework for Information Literacy for Higher Education. These competencies are essential not only in educational contexts but also in the everyday information environments of young people, including social media.

This study examines the ways in which young video bloggers construct their authoritative voices through health-related vlogging. As such, it adds to the socially oriented body of research on information literacy, viewing information literacy as not only encompassing individual-level skills related to seeking, evaluating and using information but also emerging through social and material practices (see, e.g. Lloyd, 2017). Moreover, the study contributes to an under-researched area within information studies (Huvila et al., 2020) by studying information creation as an information literacy practice. It particularly focuses on the concept of cognitive authority (Wilson, 1983) to investigate how young video bloggers use information sources to construct their own cognitive authority through health-related information creation and in relation to the viewers of their videos.

\section{Literature review}

\subsection{Information creation as an information literacy practice}

Although there is a long tradition of research on creating, producing or making informational things in other fields, these notions have not been well recognized or developed within

\section{Video bloggers constructing cognitive authority}


JD

78,7

information literacy or practices research (Kitzie, 2019; Hicks, 2020; Huvila et al., 2020). Lacking a clear definition, information creation is often viewed as synonymous or overlapping with information production and making, terms more often used in the context of digital media production (Koh, 2013), or regarded as information use, a final product of information literacy or a way to present content (Gorichanaz, 2019; Hicks, 2020). In empirical studies, information creation has been referred to as, for example, "making contributions to the information world" (Koh, 2013, p. 1826), bringing information into existence (Trace, 2007) and as documentation (McKenzie et al., 2014; Gorichanaz, 2017). To distinguish information creation as a unique concept, Koh (2013) defines it as "the way people create messages, cues, and informative content that can be used to meet the existing or potential information needs of the creator or other users", regardless of the format of this content.

In this study, information creation is understood as an information literacy practice. Following Lloyd (2010), information literacy is understood as a situated, collective and embodied sociocultural practice that "engages people with information and knowledge" (Lloyd, 2011, p. 277) and is constructed through social activities recognized in a particular setting. The notion of creating or producing information as a part of literacy activities has emerged in fields such as media education and educational sciences. Common to these conceptualizations is a broad understanding of texts, such as digital content, that appear in multimodal forms, including sound, text, images, video, animations and combinations of these (e.g. Lankshear and Knobel, 2011). Moreover, social practices related to the production of these multimodal texts are seen as contextual, transforming and emerging along with new information and communication technologies (Street, 2003; Coiro et al., 2008).

Empirical research on information creation as an information literacy practice in everyday life is scarce. Particularly relevant are the few studies that have examined the information creation practices of young people in online environments (Koh, 2013; Kitzie, 2019). For example, Koh (2013) found that the information creation process of teenagers who actively produced and shared information projects, such as online school magazines, wikis and online media libraries, included content development, organization and presentation of information, visualization and remixing of information, that is, "creative reuse of information in order to produce new information". Information creation may also serve as a way to fulfil the information needs of both the producer and receiver of information, as Kitzie (2019) showed in their study on the online identity work of American LGBTQ+ [1] millennials who created YouTube videos. The most recent studies on information creation have focused on, for example, the information literacy practices of language learners (Hicks, 2020) and the documentation practices of Bangladeshi women (Frings-Hessami et al., 2020). These studies suggest that information creation not only fulfils anticipated information needs (FringsHessami et al., 2020) or supports identity work, but is an integral part of enacting information literacy in different contexts (Hicks, 2020).

\subsection{The concept of cognitive authority from the perspective of information literacy}

"Cognitive authority" refers to human or non-human information sources that we "recognize as proper" (Wilson, 1983, p. 15) and that influence our thoughts. The influence of cognitive authority is based on credibility, which Wilson (1983) describes as having two main components: competence and trustworthiness. In a particular sphere, some people are considered to have more competence than others based on, for example, their occupational or educational expertise or experience (Wilson, 1983). However, according to Wilson (1983), it is usually assumed that people have competence at least in the sphere of their own experience. A person or source can be recognized as trustworthy if he is "honest, careful in what he says, and disinclined to deceive" (Wilson, 1983, p. 15) or "fair, unbiased, and truthful” (Rieh, 2010). 
Moreover, authority judgements can be based on performance (Wilson, 1991), reputation (Wilson, 1983; Rieh, 2010) and intrinsic plausibility (Wilson, 1983; McKenzie, 2003), among other things.

Assessments of cognitive authority are often seen as subjective and based on individuals' beliefs, knowledge and prior experiences (Rieh, 2010). Yet, they should also be viewed as socially constructed (e.g. McKenzie, 2003), and different cognitive authorities can be identified in different communities (Wilson, 1983). Moreover, these assessments are highly contextual, based on, for example, people's conceptions of the setting and type of information (Hirvonen et al., 2019).

Understanding and recognizing cognitive authority in one's own information environment can be seen as a key aspect of information literacy. Whitworth (2014, p. 24) suggests that "an information literate person must understand the reasons why cognitive authority is invested in certain texts, people and methods, as well as related issues such as ethics and legalities" and that information literacy should be understood as the "scrutiny of claims to cognitive authority in particular context". This notion relates to Papen's (2013) argument about information literacy and the question of what counts as knowledge in different situations and contexts. According to Papen (2013), information literacy research should focus more on information use, that is, the ways knowledge is put to use, how it affects people and what kind of knowledge is accepted as plausible and legitimate in certain contexts. Information creation involves information use, as information and knowledge are employed in the construction of new information (Papen, 2013).

Much of the empirical research on cognitive authority has focused on seeking and assessing information online (see, e.g. Fritch and Cromwell, 2001, 2002; Rieh, 2000, 2002) and in health settings (see, e.g. McKenzie, 2003; Oliphant, 2009; Neal and McKenzie, 2011; Doty, 2015). Studies employing a social constructionist viewpoint present cognitive authority as constructed through discourse (Tuominen et al., 2002). Particularly relevant for this study is research that has examined how different groups of people make judgements about and negotiate the authority of health information sources (McKenzie, 2003; Oliphant, 2009; Neal and McKenzie, 2011; Doty, 2015). This construction of health-related cognitive authorities has been examined by using interview and survey methods (McKenzie, 2003; Oliphant, 2009) and by observing action taking place in settings such as health education classrooms (Hirvonen and Palmgren-Neuvonen, 2019; Nygård et al., 2020) and online forums (Ma and Stahl, 2017; Doty, 2015; Oliphant, 2009), for example. The results of these studies suggest that one's own experience-based knowledge and that of others plays an integral role in justifying the authority of different information sources (McKenzie, 2003; Oliphant, 2009; Neal and McKenzie, 2011). They also reveal the contextual nature of cognitive authority construction (McKenzie, 2003; Hirvonen and Palmgren-Neuvonen, 2019; Ma and Stahl, 2017). In their study of health blogs, Neal and McKenzie (2011) found that bloggers made and disputed claims about the cognitive authority of sources they used based on multiple types of knowledge, including experiential first-hand, peer-provided, biomedical and intuitive knowledge.

Few empirical studies have examined cognitive authority from the perspective of information literacy. To study the information literacy practices of young women choosing contraceptives, Rivano Eckerdal (2011) used cognitive authority as an analytical tool to study the ways in which authority is ascribed to information sources. The findings show that trust, close relations and professional expertise were seen as important attributes when assessing the cognitive authority of different sources (Rivano Eckerdal, 2011). Hirvonen, Tirroniemi and Kortelainen (2019) explored how girls and young women perceive an online discussion forum as a potentially authoritative source of health information. The findings indicate that the participants viewed the forum as an appropriate source of experiential, rather than factual, health information and used various strategies (author-related cues, argumentation and tone, veracity and verification) to evaluate the credibility of the information shared in the

\section{Video bloggers constructing cognitive authority}


JD

78,7

forum (Hirvonen et al., 2019). The authors conclude that the members of the online forum individually or collectively - can act as cognitive authorities for other users (Hirvonen et al., 2019).

\subsection{Construction of cognitive authority through information creation}

Although assessment of the authority of sources as a part of information literacy practices has been discussed within information studies, the ways in which people construct their own cognitive authority have been empirically understudied. The Association of College and Research Libraries' (2016) Framework for Information Literacy for Higher Education stresses that authority is constructed and contextual, and that an information-literate person should be able to "acknowledge they are developing their own authoritative voices in a particular area and recognize the responsibilities this entails", including seeking accuracy and reliability, respecting intellectual property and participating in communities of practice.

Few studies have empirically examined the construction of authority or credibility through information creation. Rieh et al. (2014, p. 436) studied the ways in which bloggers establish and enhance the credibility of their blogs through blogging practices, and they presented the concept of audience-aware credibility to describe how bloggers "signal their credibility based on who they think their audience is and how they provide value to that perceived audience". The authors identified four types of bloggers who constructed audienceaware credibility in different ways: community builder, expertise provider, topic synthesizer and information filterer (Rieh et al., 2014). Talboom and Pierson (2014) used a discursive psychology approach to understand how the participants of an online discussion forum try to present themselves and the sources to which they refer as being trustworthy and authoritative. By placing emphasis on the social practices of the members of the forum instead of individuals' cognitive processes, the study explored the complex relationship between building trust and cognitive authority through content creation. The findings of the study suggest that trust is negotiable depending on the context and the effect the information providers try to achieve (Talboom and Pierson, 2014). Moreover, the results indicated that cognitive authority is constructed mainly based on professional and experiential knowledge, and the extent to which someone is recognized as a cognitive authority is linked to their reputation, expertise and experience (Talboom and Pearson, 2014).

\section{Research questions}

While a considerable body of information literacy and cognitive authority research has focused on information-seeking and credibility assessments, this study aims to improve the understanding of the information literacy practices related to information creation. Specifically, we examine young video bloggers as they create health-related YouTube videos and, in doing so, construct their cognitive authority (Wilson, 1983). The research questions (RQ) are set as follows:

$R Q 1$. What kinds of information literacy practices do video bloggers employ during the information creation process?

$R Q 2$. How do video bloggers construct their cognitive authority in this process using different information sources?

\section{Methodological perspective}

This study adopts nexus analysis as a methodological perspective from which to investigate young video bloggers' actions and discourses during the information creation process. Nexus 
analysis (see also mediated discourse analysis, Scollon and Scollon, 2004) can be understood as both a form of ethnography and an action-oriented approach to discourse analysis (Scollon and Scollon, 2004). This multidisciplinary methodology has roots in research traditions such as interactional sociolinguistics, linguistic anthropology and critical discourse analysis (Lane, 2014; Hult, 2017; Kuure et al., 2018), and its primary focus is on the complex relation between social action and discourse (Scollon and de Saint-Georges, 2011; Lane, 2014). Several research traditions focus on studying social action, but in practice, they often tend to foreground spoken or written discourse and consider everything else to be merely "context" (Scollon, 2001). The consideration of non-linguistic and embodied practices, in addition to language use, is considered needed also in information literacy research, particularly when unfolding "the tacit and contingent forms of knowledge [...] often hidden in everyday activities" (Olsson and Lloyd, 2017).

In nexus analysis, consistent with practice theoretical and socio-cultural approaches, cultural tools, such as semiotic resources and technological applications (Lane, 2014), are viewed to mediate action; they are mediational means that, when appropriated by particular people in particular situations, "make certain kinds of actions more possible (and other kinds of actions less possible)" (Jones, 2020, p. 202). Nexus analysis situates social action at the intersection of the historical bodies of people engaged in the action, the mutually produced interaction order and the discourses in place that enable or disable action and/or are used by participants as mediational means (Scollon and Scollon, 2004; see Figure 1).

Discourses in place refers to the wide range of discursive elements circulating through any social action. In nexus analysis, discourse is understood as a two-level construct, according to Gee (1999): small-scale discourse describes language that is used "in site" (Lane, 2014), and large-scale Discourse (with a capital D) refers to "larger structures of social organization" (Norris and Jones, 2005, p. 10). The focus of analysis is placed on discourses that are relevant to the given scene, meaning those that the actors use as mediational means (Lane, 2014). Understood from both narrow and broad perspectives, various discourses circulate through the actions of people, of which some are considered as mediational means in the social action

\section{Video bloggers constructing cognitive authority}

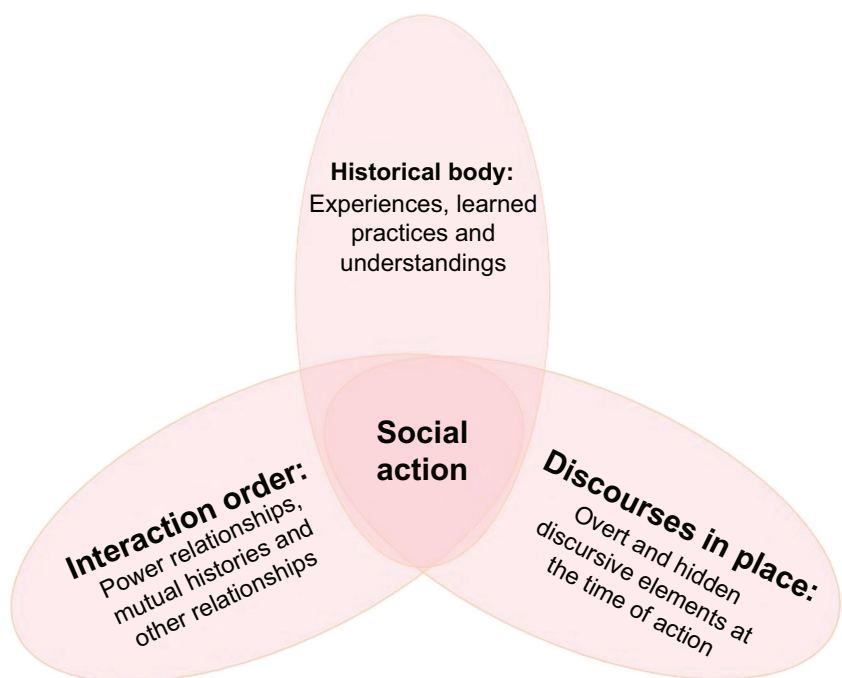

Source(s): Adapted from Scollon and Scollon (2004)

Figure 1. Three key elements of social action 
JD

78,7

(Larsen and Raudaskoski, 2018). Nexus analysis makes use of Goffman's (1983) term interaction order to understand the social arrangements by which people form relationships in social interactions (Scollon and Scollon, 2004). These arrangements may imply, for example, roles adopted in a certain scene, power relations or mutual histories. In social situations, people tend to adhere to their expected roles, which are shaped historically and culturally by earlier experiences (Räisänen, 2015). The notion of historical body (see, e.g. Nishida, 1958) refers to the bodily memories - that is, the previous experiences, learned practices and understandings - that people bring with them to every scene of action (Scollon and Scollon, 2004). The concept is inspired by Bourdieu's (1977) notion of habitus, but it adopts a more dynamic and organic perspective (Scollon and Scollon, 2004). The historical body is seen not only as internal storage of past experiences but also as a set of embodied actions that are used so often they become nearly automatic (Wohlwend, 2020), serving as the basis for the development of new social practices (Larsen and Raudaskoski, 2018). Thus, the historical body is something that unfolds over one's individual life span (Hult, 2019).

These central elements of social action are seen to be inseparably connected, intertwined and reciprocally shaped at a specific moment in time (Lane, 2014). For this study, they offer an analytical toolset to understand the social action of vlogging from different perspectives. Moreover, by following the guidelines for nexus analysis (Scollon and Scollon, 2004) on triangulating data and combining elements from various approaches, this study seeks to unfold the historicity and situatedness of information practices related to vlogging.

\subsection{Data collection and analysis}

The empirical data for the study were collected between December 2018 and June 2019. First, three young video bloggers aged 15-24 years were recruited to the study. This age group was chosen as it represents the official definition of youth by the United Nations (UNESCO, 2021). Potential participants were identified by screening health-related YouTube accounts and contacted by email and via social media. Other than being Finnish and having health-related content on their YouTube accounts, no specific criteria were set for participation in the study. Of the contacted candidates, three young women, aged 16, 22 and 24 years, with different backgrounds on vlogging, agreed to participate in the study. The 16-year-old participant had a five-year experience on vlogging, on topics such as making slime [2] and studying in high school. On her YouTube account, she had 39,000 followers who were, according to her, mainly younger children. The 24-year-old participant was a beginner in vlogging and had only few videos and followers on YouTube. She was interested in making videos especially on health topics. The 22-year-old participant had six years of experience on writing a blog, and had created her YouTube-account recently. She had made videos about her psychology studies at the university, including autonomous sensory meridian response (ASMR) [3] videos and topics such as mental health. She already had over 3,800 followers on YouTube, who were, according to her, mostly students of her own age.

Following the nexus analytical research process (Scollon and Scollon, 2004) and to increase credibility of the study through triangulation (Lincoln and Guba, 1985), different types of data were collected with the participants:

(1) interview data, which were collected by interviewing the participants before and after they published the YouTube video,

(2) video diary data of the video production process and

(3) YouTube videos that the participants published (see Table 1).

The participants were asked to choose a topic and create a new health-related video on their YouTube accounts and report this process in a video diary. For the video diary, they were 
asked to describe the planning of the video, including used information sources and ideas regarding presentation. Moreover, they were asked to reflect the whole creation process, also including the response they received from their audience after the video was published. The participant interviews were conducted as unstructured interviews (see, e.g. O'Reilly and Dogra, 2017), themed with topics such as participants' background and experience in vlogging, information-seeking and assessment, and health in general. The participant interviews $(N=3)$ were audio-recorded and varied in length from $23 \mathrm{~min}$ to $1 \mathrm{~h} 5 \mathrm{~min}$. In total, $4 \mathrm{~h}$ and $20 \mathrm{~min}$ of audio data were collected from the interviews. Video diaries ranged from 5 to $10 \mathrm{~min}$ in length, resulting in a total of $23 \mathrm{~min}$ of video data. The length of the YouTube videos published on the participants' accounts varied from 8 to $18 \mathrm{~min}$, for a total of $34 \mathrm{~min}$ of video data. In total, the data comprise $5 \mathrm{~h} 18 \mathrm{~min}$ of audio and video data.

Although only three young women participated in the study, they produced a rich set of multimodal data representing the complex process of creating a video on YouTube. Data triangulation was performed to give insight into the social actions of the participants from different perspectives during the process of information creation. In order to further ensure the dependability (Lincoln and Guba, 1985) of the study process, the data were transcribed verbatim, qualitatively analysed and annotated by the first author using the qualitative analysis software QSR NVivo. Data analysis was guided by the three key elements of social action central to nexus analysis: discourses in place, interaction order and historical body. Appendix provides a description of how the elements were used in the data analysis (see also Räisänen, 2015; Multas and Hirvonen, 2019). The analysis concentrated on identifying the information literacy practices, including seeking and using information sources that were employed in the social action of creating a health-related video blog. The interviews and video diaries enabled exploring how the participants generalized their actions and experiences and how they described their interactions with others, providing insight into the information literacy practices that the participants employed prior to publication of the video. Observation of the final videos allowed to consider, among other things, what the participants decided to present for their audience. Member checking (e-mails with the participants about remarks made during the analysis and findings) and peer debriefings (regular researcher meetings and data sessions) were conducted to ascertain credibility and confirmability of the data (Lincoln and Guba, 1985).

\subsection{Ethical considerations}

During the research process, the authors followed the guidelines for empirical research ethics, including consent procedures for the humanities and social and behavioural sciences (Finnish Advisory Board on Research Integrity, 2019). Written consent was obtained from the participants before data collection. The descriptions and pictures of the videos presented in this article may provide enough information to identify the participants. However, when writing this article, the participants gave their additional permission to include these descriptions. All names presented here are pseudonyms.

\begin{tabular}{|c|c|c|c|c|c|}
\hline Data, minutes [identifier] & Jane & Emma & $\begin{array}{l}\text { ipant } \\
\text { Laura }\end{array}$ & Total & \\
\hline Pre-interview & 66 [Jane_pre] & 55 [Emma_pre] & 65 [Laura_pre] & 186 & \\
\hline Video diary & 5 [Jane_diary] & 8 [Emma_diary] & 10 [Laura_diary] & 23 & \\
\hline YouTube video & 8 [Jane_video] & 8 [Emma_video] & 18 [Laura_video] & 34 & Table 1. \\
\hline Post-interview & 24 [Jane_post] & 26 [Emma_post] & 25 [Laura_post] & 75 & The collected data by \\
\hline Total (min) & 103 & 97 & 118 & 318 (5h $18 \mathrm{~min})$ & type and participant \\
\hline
\end{tabular}

\section{Video bloggers constructing cognitive authority}


$\mathrm{JD}$

78,7

50

\section{Findings}

The findings are presented by describing the individual information creation process of each video blogger including the central elements of social action - discourses in place, historical body and interaction order. The point of departure for each description is the YouTube video created by the video blogger. Although the video is the end result of the information creation process, it is described first to present the ways in which video bloggers constructed their cognitive authority in relation to their audience. The other data - video diaries and pre- and post-interviews - provide insight into the process of creating the videos.

\subsection{Jane: constructing cognitive authority with experience-based information}

Jane's YouTube video is seven and a half minutes long and highlights her experiential knowledge on stress, the topic she chose for the video. In the video, she is wearing a yellow hoodie, sitting in front of a white wall with a plant behind her (Figure 2). Throughout the video, she faces the camera, talking to her anticipated audience. Her gestures are vivid; she touches her hair, she uses her hands while talking and her facial expressions are lively. In the beginning of the video, Jane mentions her appearance, saying that she "looks weird" without makeup, but "let's keep this video as real as possible, and honest". She then introduces the video: "We people stress about so many things, and so today I'm here talking to you about stress". She continues by listing things about which she is stressed, including schoolwork, her sleep cycle, making YouTube videos, being different and not having friends. Then, she shares stress relief tips she has found useful. As she talks, text such as "say things aloud", "write stories" and "plan and schedule" and pictures of a teacup and headphones appear on the screen. Jane's final tip concerns schoolwork and deadlines. She explains her recent experience with a school task and encourages viewers to ask for extensions on deadlines, as she did. In the end of the video, Jane notes, "it is normal that you stress". She continues by reminding the viewers that "you need to offer yourself rest and have self-mercy". She ends the video by saying "I love you all so much! This is all from me. See you and bye!", and she blows a kiss to the viewers [Jane_video].

Jane's authority appears to be constructed mainly on the trustworthiness that she builds by presenting herself as authentic and by explaining her first-hand experience with the topic. She presents herself clearly, and she seems comfortable in front of the camera; talks to the

Figure 2.

An anonymized screenshot of Jane's YouTube video [Jane_video]

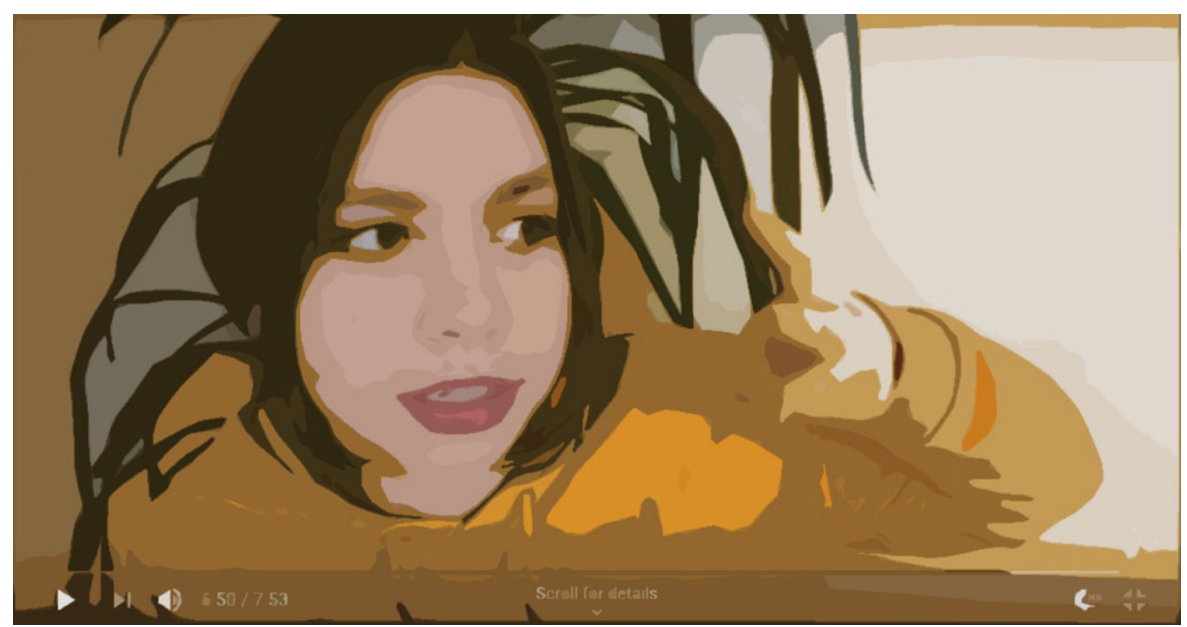


viewers in a familiar manner; does not wear makeup; and states that she will try to keep the video real and honest. By presenting herself as authentically as possible, Jane builds trustworthiness among her anticipated audience. The way Jane constructs the video appears to be strongly guided by the visual discourse and the practices of the vlogging community. Specifically, the structure and style of the video seem to follow the conventions of a "topic video", in which video bloggers talk and share their opinions about a certain topic.

Jane's information practices during the information creation process included planning the video and seeking and remixing information. In the video diary, Jane explained that, during the planning process, she had employed a range of tools to find information, such as her mobile phone and laptop, and she had called her sister to discuss topics. She found an online health library article with eleven tips on how to deal with stress, saying in the video diary that those tips were "really reasonable" and that she "would definitely use some of them" [Jane_diary]. In the post-interview, she commented that she used the tips "to give direction" and that she wanted to use them as a basis for the video as they "felt close" to her own experiences. Although she searched for additional information by googling the word "stress", Jane does not mention the use of other information sources in the video [Jane_post]. The analysis indicates that although Jane employed remixing (Koh, 2013) of first-hand and second-hand information in the information creation process, in the final video first-hand information is emphasized.

Jane's talk and actions while creating the video foreground two relevant discourses in place regarding the use and credibility assessment of information sources: one prioritizing firsthand information based on her own experiences and another emphasizing credible and acceptable sources of second-hand information (Wilson, 1983). The importance of first-hand experience to Jane is emphasized in the post-interview, in which she explained that she wanted that the topic to be "current" for herself so that she "would have naturally more to say" about it. As such, the video creation process fulfilled her own current information needs [Jane_post].

The pre-interview provided insight into the previously learned information practices regarding second-hand information. Jane talked about typical ways that she sought information and selected sources:

Researcher: What do you think about Wikipedia, as you said that it is embarrassing to say that [Wikipedia was the first source you searched]?

Jane: Well, the way that ... I do not know. Somehow I have that impression that, for example, in school, they say that do not go to Wikipedia to find information, so ... that has left me the feeling that [information] on Wikipedia is not necessarily true ... [Jane_pre]

The discussion about Wikipedia echoes the, perhaps quite common (see, e.g. Hirvonen and Palmgren-Neuvonen, 2019), school discourse about acceptable information sources. Jane said that the topic had been addressed in school and, for example, when doing school presentations and other tasks in school, her teachers had stressed the need to use other sources in addition to Wikipedia because "there is the possibility that anyone can edit" the latter. However, Jane's own opinion on the subject somewhat differed: "if you think of it with common sense, if you read something in there that is suspicious for you, you can always check it" [Jane_pre]. This resembles what Wilson (1983) describes as intrinsic plausibility, meaning the instant recognition of information as "eminently sensible" or implausible.

Aspects of Jane's historical body regarding vlogging surfaced specifically in the pre-interview. At the time she created the video, Jane was already an experienced video blogger. At 16 years old, she had been vlogging for almost five years and was accustomed to making "topic videos" similar to the video she made for this study. She learned the practices of vlogging, such as editing, by herself. Jane's native language is Finnish, but she is also fluent 
$\mathrm{JD}$

78,7

\section{2}

in another language, which helped her to seek a greater variety of information on different topics. According to Jane, her aim in vlogging was to present her true personality and "just altogether who I am". When asked about her feelings and thoughts regarding her influence on her audience, she said, "When I was making the video [about a vegan diet], I thought that I could really influence what people are doing" [Jane_pre].

The multimodal data foreground different discourses and relationships reflecting the interaction order among the people involved. For example, in the YouTube video, Jane takes on an adviser role, grounded in her own experiences with the topic rather than second-hand information. On the other hand, in the interviews and video diary, Jane adopts the position of an informant and refers to school norms regarding source credibility, perhaps to meet the expectations of the researcher.

\subsection{Emma: constructing cognitive authority with embodied knowledge}

Emma's YouTube video is almost eight minutes long and emphasizes her embodied knowledge about a healthy lifestyle. The video starts by presenting the name of a skiing resort and the year 2019 with upbeat pop music in the background. Then, it shows Emma's flight landing and her arrival at a cabin where her family will stay. Next, she and her boyfriend engage in different activities, such as downhill skiing (Figure 3), a husky safari and a snowmobile ride. Emma and her boyfriend take turns filming the video, sometimes with a selfie stick and sometimes by hand. Most of the time, a regular lens is used, but at times the video shifts to a fisheye lens. Often, the scenery at the filming locations is shown, highlighting the sunny and snowy winter weather in Lapland. The music is the only sound in the video, and it continues until the end. Within the last few minutes of the video, however, the music changes from pop to mellow instrumental music. It ends on a frame with a pink background colour and illustrated flowers on the right side. On the left, there is a caption, "Thanks for watching”, and Facebook and Instagram logos with Emma's usernames [Emma_video].

In the YouTube video, Emma's cognitive authority appears to be constructed on the embodied knowledge she gained through her active and healthy lifestyle. In the visually narrative video, Emma seems happy and relaxed; she smiles and looks at the camera. In the video diary, Emma explains that she decided to film the video during a winter vacation she

Figure 3.

An anonymized screenshot of Emma's YouTube video [Emma_video]

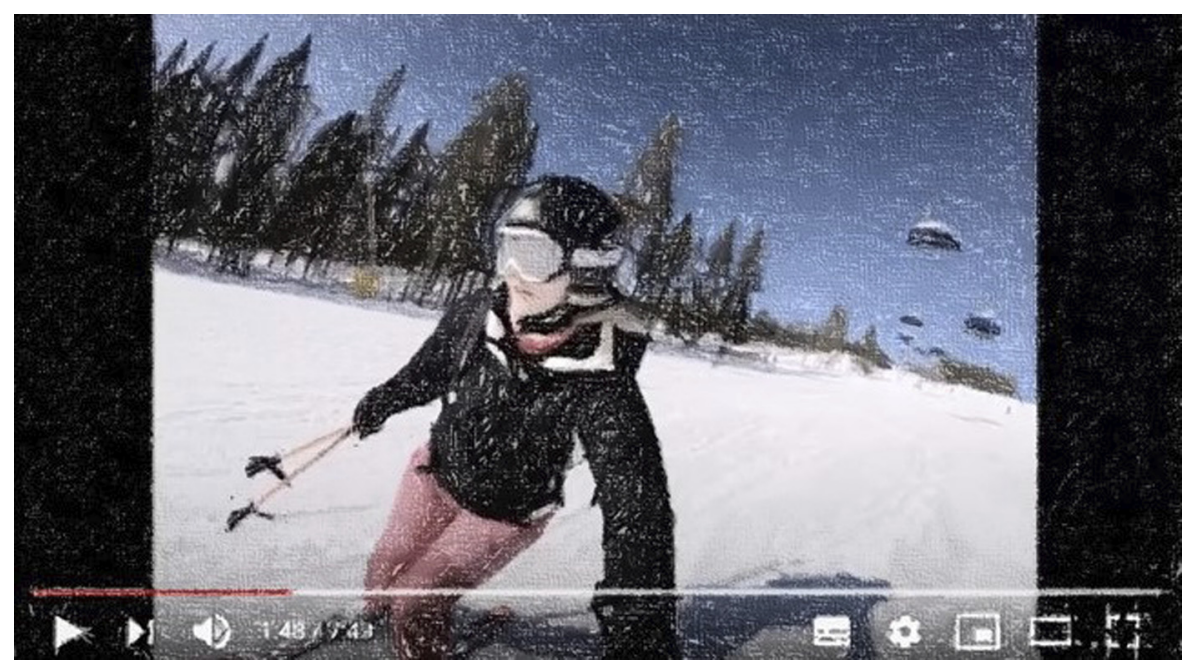


and her family took to a skiing resort in Northern Finland. She described that she planned to make the YouTube video as "a summary, like of the whole trip". She explained that the aim was to describe how she achieves physical and mental health by participating in sports and experiences that can be done in Lapland, as well as "how you can draw energy from nature". Showing or manifesting embodied actions (Olsson, 2010a, b) is a way in which authority can be constructed based on performance (Wilson, 1991), among other things.

Information-seeking did not appear to be a central information practice for Emma when she created her video. She explained in the pre-interview that for her, in general, informationseeking on health mainly took the form of googling interesting topics that she came across online and "just jumping on site to site to find out what they offer". She also used YouTube to find relevant information on certain topics and "looked if someone had done" a video on the topic [Emma_pre].

When talking about the credibility of health information sources, she described her method of credibility assessment, which was rather intuitive:

Researcher: What kind of health information is, in your opinion, useful or good for you?

Emma: Well, I guess, just like, maybe like... I can see from the site that it's like trustworthy. That it's not like some... you can see it in there from the page whether you can trust the text or not. Yeah, from there. [Emma_pre]

In the post-interview, she described how she had searched for suitable music: "I searched from the internet with different search terms... where I can find that kind of legal music which would altogether be suitable for it" [Emma_post].

A discourse on authenticity in social media was the most apparent discourse in place throughout Emma's data. In the pre-interview, Emma described authenticity as essential for a health-related YouTube channel. For example, when discussing the general trustworthiness of video bloggers, Emma stated, "you can be credible when you are yourself and do not try to act anything". She explained that, "for me, it's like, be your own genuine self, it does not need anything else". Emma said that you could easily notice if a video blogger is not their genuine self in a video. According to Emma, her own joy motivated her to create the videos, and she wanted to appear in the video as genuine and authentic. This can be described as a means to build trustworthiness in relation to the anticipated audience [Emma_pre]. In the video diary, Emma said that she wanted to film spontaneously so that the video looks "as authentic as possible in the stage of the publication". She expressed that she wanted to have a good feeling about the video and to be satisfied with the result [Emma_diary]. Through the strong visual narrative in her video and the grounding in her embodied knowledge on health, Emma was able to express her values and show viewers how she achieves good health.

The pre-interview revealed aspects of Emma's historical body. At 24 years of age, she had been doing different types of videos on YouTube, but in the future, she wanted to concentrate on health topics because she had been pursuing a healthier lifestyle for a while. A desire for a career in the wellness business served as motivation for making YouTube videos. As she considered herself to be a beginner at vlogging, she wanted to learn to edit and use different tools as a hobby [Emma_pre]. In the post-interview, when she explained how she searched for legal music for the video, she explained that she is "not a top" video blogger and that she has not been able to familiarize herself with the process of finding good music for YouTube videos [Emma_post].

Emma's lack of experience in vlogging was also an important aspect in terms of interaction order. In the interviews and video diary, for the researcher, Emma positioned herself as a beginner in vlogging by stating it clearly and describing it as a hobby that she is still learning [Emma_pre, Emma_post, Emma_video diary]. However, the lack of experience is not evident in her technically well executed YouTube video. Moreover, Emma did not

\section{Video bloggers constructing cognitive authority}


JD

78,7

\section{4}

Figure 4.

An anonymized screenshot of Laura's YouTube video [Laura_video] appear to have close relationship with her audience as the video lacks direct verbal communication with the anticipated audience and concentrates on exhibiting Emma's performance in different physical activities.

\subsection{Laura: constructing cognitive authority with scientific information and educational} expertise

Laura's YouTube video is 18 min long and emphasizes her educational expertise (Wilson, 1983) gained through her studies. In the video, Laura is sitting on her apartment's balcony and talking to the camera (Figure 4). The video is visually plain and filmed with only a few takes. Laura explains that she has been doing YouTube videos for six months and that her autonomous sensory meridian response (ASMR) videos have been popular among her followers. She continues to talk about ASMR: what it is and the reasons why she wanted to tell the audience more about it. Moreover, she describes the scientific studies she had found on ASMR. While talking, she engages her hands, and she seems relaxed and comfortable. When explaining the "tingle" often produced by ASMR, Laura raises her hand to her head for emphasis. At the end of the video, she tells the audience, "it was interesting to go through these studies, as the scientific background of ASMR is not familiar to me", expressing that she hopes "you learned something from this video and now understand more about ASMR and what it is". She explains that she will add related links to the description section of the video and that, in the future, she will make more videos that "discuss these kinds of phenomena and things from the perspective of psychology science". She ends the video by saying, "until those videos, see you and thanks for watching the video", then blows a kiss and says, "Bye!". The end frame includes text saying, "subscribe to the channel", and a link to another video from her channel [Laura_video].

In the YouTube video, Laura appears to construct her cognitive authority through her own competence, which was grounded on her educational expertise (Wilson, 1983) and supported with scientific information. In the visually plain video, Laura presents herself clearly and in a professional manner when talking about the studies she had searched for the video, and tells her viewers, "and in this video I will tell you what I found". Although Laura explained in the video diary that she had prepared a manuscript for the presentation, this is

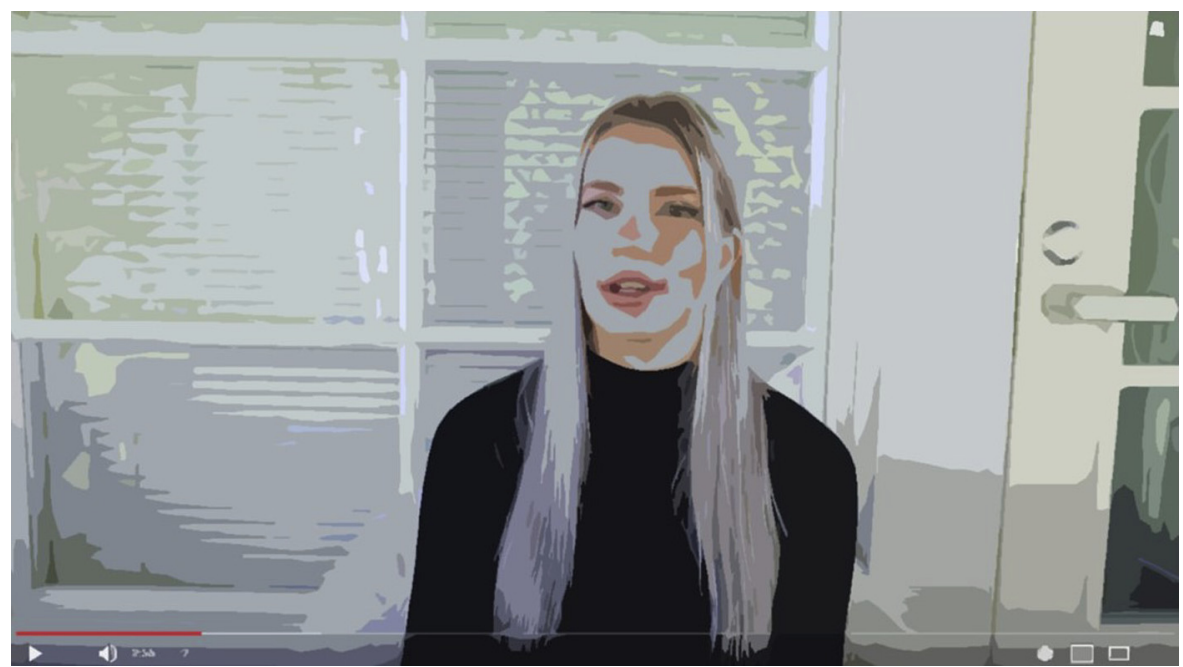


not in any way apparent in the video [Laura_diary]. She thoroughly describes the findings of the studies, including the causes of the ASMR sensation, what kinds of effects it has on people's well-being and what results neuroscience research has reported, and she even mentions the institutions with which the studies were affiliated. This way, she emphasizes her competence and, as such, credibility towards her anticipated audience.

Laura's information practices for the new YouTube video included information-seeking, taking notes on the scientific articles, writing a manuscript and printing it out to help organize the presentation of the information in the video [Laura_diary]. Her information-seeking when making a new video included checking the facts so that "the information I have at the moment, are they at the moment, like still accurate so that there isn't something stuck with me on the way". The first stage of information-seeking for a video includes checking her own material:

The researcher: Where do you first start to seek information?

Laura: Well, if there's, well, mainly from like the material that have been gathered during the studies, so some sources, literature that have stuck with me or lecture notes, and then I have gathered, like, the notes from the studies and stuff to a folder where they are safe. [Laura_pre]

Moreover, she explained that she usually seeks for more information from the university library database. Sometimes, she knows a researcher at her university who has studied the topic in which she is interested, so she can "search directly with the name" [Laura_pre]. As Laura had not previously familiarized herself with scientific information about ASMR, participating in this study was an opportunity to fulfil her information need about a subject in which she was interested (Koh, 2013) [Laura_diary].

Based on all the data types (interviews, video diary, YouTube video), the central discourse in place concerning Laura's information creation process was the discourse of credibility related to the scientific knowledge with which she worked with on a daily basis in her studies and used in the video. For Laura, the use of scientific information indicated the credibility of a YouTube video: "if there is not any scientific ground, so it kind of eats its own credibility to the topic" [Laura_pre]. In the post-interview, she explained how she assessed the credibility of the sources she found: "Well, for example, some of them were like those that were cited often and published in some reasonably good journals. And the sample sizes and methods seemed reasonable and the study was conducted like, following good research and scientific [principles]" [Laura_post]. Thus, Laura's competence to assess the quality of scientific articles had a strong influence on her actions while making the video.

The pre-interview revealed aspects of Laura's historical body: experience with vlogging and her motives and ideas for making YouTube videos in general. At 22 years old, she had six years of experience in writing a blog. She wanted to start making videos on YouTube because, based on discussions with her younger friends, she felt that blogs were not popular anymore. In addition, she wanted to have more interaction with her readers and followers. When starting her channel, she had limited her videos to health topics, especially mental health, as she studied psychology at university. She also wanted to make videos about studying psychology and, for example, entrance examinations. For Laura, the experience she had gained through her studies indicated her competence: "and as I am studying psychology, so I know things" [Laura_pre]. Previously, she wrote about similar topics on her blog and created study materials for people intending to take psychology entrance examinations. For her, it was important that she had experience on the topic of the video, that the video fit the theme of her channel and "that I can get some kind of quality content out of it" [Laura_pre].

In the video diary, Laura presented different sources she had found on ASMR. She used Google Scholar to find articles as well as her university library's databases and the PubMed online medical archive. In addition, she had found a YouTube video presenting a research 
$\mathrm{JD}$

78,7

interview and a science blog post written by a psychologist. She explained that she used two workdays to find and review the studies, and that she chose to make the video because she did not have any background information on the topic. In the video, she wanted to be convincing: "somehow when making this type of scientific video, there is a big pressure on that everything is $100 \% \mathrm{OK}$, and that the video has to be convincing". These notions give insight to the interaction order within the social action of Laura's information creation process. Laura wanted to be convincing towards her anticipated audience, but also in relation to the researcher. When asked whether participation in the study had an influence on her ways to create the video, Laura explained that she did the video "more carefully" because of it, searched more information and "somehow paid more attention to these things" [Laura_post]. Moreover, Laura's thorough way of creating new information represents aspects of the norms and conventions of information-seeking within university studies and scientific research in general.

\section{Discussion}

In this study we examined the information practices young video bloggers employ when creating a health-related YouTube video and how they construct their authoritative voices through the information creation process. The results indicate that video bloggers employ several information practices, including planning, information-seeking, organization, editing and presentation of information. These findings are similar to those of Koh (2013), who found that content development, organization and presentation of information were important steps in the information creation process of teenagers actively producing and sharing information objects. Although the participants in this study employed similar information practices, unique aspects were also identified. For example, information-seeking served different purposes in their creation process and was not central for all of them. For Jane and Laura, information-seeking was a central phase of content development and planning. In contrast, Emma searched for information after filming the video, as her need for second-hand information came apparent only in the editing phase.

In the presentation phase, Jane and Laura employed different practices to organize the information they found. Similar to the study by Koh (2013), this study identified the information practices of remixing and visualization, especially in Jane's information creation process, as she remixed second-hand information with her own experience-based information about the topic. To visually emphasize her message, Jane incorporated text captions and pictures into the video. Thus, she used multimodal information, which Lankshear and Knobel (2011) describe as central to the social practices of "producing, distributing, exchanging, and receiving texts by electronic means (emphasis in original)". For Laura, checking facts, making notes and writing a manuscript were important information practices for organizing the information she found. The manuscript served to gather the results of her intensive information-seeking into a more presentable form.

Emma seemed to heavily rely on her own embodied knowledge in most phases of the information creation process. This aligns with the final YouTube video she created, as in it she models embodied practices used in activities such as downhill skiing and a snowmobile safari. A similar emphasis on embodied knowledge was found in Olsson's studies, which discussed the performative nature of information practices; he recognized ways in which theatre professionals (Olsson, 2010a, b) and archaeologists (Olsson, 2016) embodied their knowledge and manifested their abilities to gain recognition from community members, and that can serve as sources of authority. Different ways of embodied expression are emphasized in many of the social media services of today.

In this study, the video bloggers used information sources in different ways to construct their authoritative voices in relation to their anticipated audience. Both Jane and Emma 
constructed their cognitive authority through trustworthiness, creating genuine and believable presentations of themselves. However, the ways in which they did so differed. Jane grounded her trustworthiness in experience-based, first-hand information (see, e.g. McKenzie, 2003; Oliphant, 2009; Neal and McKenzie, 2011), although she used second-hand information for guidance. Emma, on the other hand, foregrounded her embodied knowledge about a healthy lifestyle to build a trustworthy and genuine image of herself. The emphasis on trustworthiness resembles Neal and McKenzie's (2011) conceptualization of an affective authority whose influence is based on "subjectively appropriate, empathetic, emotionally supportive, and/or aesthetically pleasing" health information (Neal and McKenzie, 2011). This is in line with Balley et al.'s (2020) findings that the feeling of closeness and the need to be recognized by others are central for young people creating YouTube videos.

While Jane's and Emma's competence seemed to extend only to the sphere of their own experience (Wilson, 1983), Laura's competence and credibility were grounded in her educational expertise and second-hand scientific information. These findings resemble previous research on health-related cognitive authorities highlighting experience-based and biomedical knowledge as a basis for authority (McKenzie, 2003; Oliphant, 2009; Neal and McKenzie, 2011). Rieh et al. (2014) identified different types of bloggers based on the way in which they constructed audience-aware credibility and provided value and credible information to their imagined audience. The expertise provider and information filterer types (Rieh et al., 2014) particularly resonate with the way in which Laura provided in-depth and detailed information on the selected topic and compiled and organized content collected from a wide range of sources.

This study provides novel knowledge on information creation as an under-researched area in information studies. The findings highlight the complexity and centrality of information creation as an information literacy practice. To be more specific, based on the findings, the information creation process appears to be composed of several interconnected social, material and embodied information literacy practices, including planning, information-seeking, organization, editing and presentation. These practices are highly contextual, but at the same time influenced by broader discourses, which in the case of this study were connected to the norms and practices of the social media environment and other everyday contexts of young people. Future research should pay attention to the conceptualization of information creation and avoid oversimplifying it to information use or as a mere end product of the process (see also Hicks, 2020).

Particularly in social media, the created information is eminently multimodal and grounded on a remix of different types of information, including experience-based, embodied and scientific information, for example. Navigating in social media environments - and use, evaluate and create information within these - necessitates a versatile set of competencies not considered in most information literacy frameworks. Moreover, in social media, young people are often in positions where they can influence others and be recognized as potential cognitive authorities. Therefore, specifically in these environments, the recognition of authoritative voices of others and, in particular, of oneself (see Association of College and Research Libraries, 2016) should be acknowledged as an integral part of the information creation process and, as such, intrinsic for information literacy. These notions should be taken into account both in information literacy research and in practical instruction, specifically if the aim is to consider information literacy practices relevant in everyday life. Practical learning tasks that include information creation can be fruitful, especially if they include creation of different information types, grounded both on first-hand and second-hand knowledge, that can potentially appear credible and authoritative in a specific sphere. These tasks ought to support differentiating between trustworthiness and competence when creating information and considering what these, as components of credibility, can be based on. Reflecting one's own authority and the responsibility that follows from that authoritative position is 
$\mathrm{JD}$

78,7

important and should be encouraged in information literacy instruction. Overall, information creation tasks can support learners in evaluating the credibility and influence of different information sources.

Nexus analysis was used as a methodology in this study to discover not only the discursive descriptions of the information creation process but also how discourses, interaction order and historical bodies of participants enabled the action under study. Consideration of these elements and the combination of different data allowed for a richer investigation of different phases of the information creation process and its end result. As the study was limited to only three participants, the findings cannot be straightforwardly generalized beyond this limited context. However, to some extent, they can be considered transferable (Lincoln and Guba, 1985): The notion of cognitive authority as central to information creation is likely to be relevant in contexts beyond the one in this study. Moreover, the findings suggest that the video bloggers' actions followed the established practices of the wider vlogging community, and that this community influenced the ways in which they constructed their cognitive authority in relation to their audience. Thus, the actions of the individual video bloggers described in this study can be understood to represent broader interpersonal, community and societal practices related to producing content and exerting influence via social media (Hult, 2017). The trustworthiness of the study was enhanced by promoting the credibility, transferability, dependability and confirmability of the study process as a whole (Lincoln and Guba, 1985). This was done by employing data triangulation, peer debriefings and member checking and including thick description of data collection, findings and interpretations of the data.

\section{Conclusions}

This study improves the understanding of the complex ways in which young people create information on social media and influence their audiences. Not only have social media services such as YouTube become central sources of information, but they are platforms for performance, peer support and social recognition (Balleys $e$ t al., 2020). This study emphasizes the significance of both trustworthiness and competence as key components of credibility in this setting. The findings suggest that video bloggers can ground their credibility on an authentic and genuine presentation that builds trustworthiness among the audience. On the other hand, they can emphasize their competence, either limited to the sphere of their own experience (Wilson, 1983), which is often central in social media, or extended beyond it to include second-hand information and expertise gained through formal education, for example.

The study contributes to information literacy research by offering insights into the under-researched area of information creation. This study is among the few to examine the construction of cognitive authority in this process. In particular, the notion of authority as constructed through trustworthiness and competence and grounded on different types of information, can be taken into account in practice by information professionals and educators when planning information literacy education. Especially learning tasks including information creation can help people to understand the ways in which cognitive authority is constructed in their information environments and to recognize their own authoritative voices.

The methodological approach applied in this study revealed not only what was said but also how language, embodied practices and technological tools were used to mediate action. This enabled a deeper understanding of how different information types - experience-based, embodied and scientific - were used to create new information. In order to broaden and diversify the research on this topic, future studies should triangulate multimodal data to investigate information creation as an information literacy practice and include more diverse group of participants. 


\section{Notes}

1. LGBTQ+ refers to lesbian, gay, bisexual, transgender, queer or questioning, and other sexual or gender identities of people.

2. Slime is a squishy polymer substance that can be made from a mixture of household items.

3. ASMR is a popular type of video on YouTube in which the video producer talks very quietly, almost whispering, into a microphone, scratches different surfaces or makes sounds with their mouth to produce a tingling experience for the viewer.
Video bloggers constructing cognitive authority

\section{References}

Anderson, M. and Jiang, J. (2018), Teens, Social Media and Technology 2018, Pew Research Center, available at: https://www.pewresearch.org/internet/2018/05/31/teens-social-media-technology2018/ (accessed 30 April 2021).

Association of College and Research Libraries (2016), "Framework for information literacy for higher education”, available at: www.ala.org/acrl/standards/ilframework (accessed 2 February 2021).

Balabanis, G. and Chatzopoulou, E. (2019), "Under the influence of a blogger: the role of informationseeking goals and issue involvement”, Psychology and Marketing, Vol. 2019 No. 36, pp. 342-353, doi: 10.1002/mar.21182.

Balleys, C., Millerand, F., Thoër, C. and Duque, N. (2020), "Searching for oneself on YouTube: teenage peer socialization and social recognition processes", Social Media + Society, Vol. 6 No. 2, pp. 1-11, doi: 10.1177/2056305120909474.

Bourdieu, P. (1977), Outline of a Theory of Practice, Cambridge University Press, Cambridge.

Coates, A.E., Hardman, C.A., Halford, J.C.G., Christiansen, P. and Boyland, E.J. (2019), "Social media influencer marketing and children's food intake: a randomized trial”, Pediatrics, Vol. 143 No. 4, e20182554, doi: 10.1542/peds.2018-2554.

Coiro, J., Knobel, M., Lankshear, C. and Leu, D.J. (2008), "Central issues in new literacies and new literacies research", in Coiro, J., Knobel, M., Lankshear, C. and Leu, D.J. (Eds), Handbook of Research on New Literacies, Lawrence Erlbaum Associates, New York, pp. 1-21.

Cusack, L., Desha, L.N., Del Mar, C.B. and Hoffmann, T.C. (2017), “A qualitative study exploring high school students' understanding of, and attitudes towards, health information and claims", Health Expectations, Vol. 20 No. 5, pp. 1163-1171, doi: 10.1111/hex.12562.

Doty, C. (2015), "Social epistemology and cognitive authority in online comments about vaccine safety", iConference 2015 Proceedings, available at: http://hdl.handle.net/2142/73664 (accessed 30 April 2021).

Finnish Advisory Board on Research Integrity (2019), "The ethical principles of research with human participants and ethical review in the human sciences in Finland", available at: https://tenk.fi/ sites/tenk.fi/files/Ihmistieteiden_eettisen_ennakkoarvioinnin_ohje_2019.pdf (accessed 30 April 2021).

Frings-Hessami, V., Sarker, A., Oliver, G. and Anwar, M. (2020), "Documentation in a community informatics project: the creation and sharing of information by women in Bangladesh", Journal of Documentation, Vol. 75 No. 2, pp. 552-570, doi: 10.1108/JD-08-2019-0167.

Fritch, J.W. and Cromwell, R.L. (2001), "Evaluating internet resources: identity, affiliation, and cognitive authority in a networked world", Journal of the American Society for Information Science and Technology, Vol. 52 No. 6, pp. 499-507, doi: 10.1002/asi.1081.

Fritch, J.W. and Cromwell, R.L. (2002), "Delving deeper into evaluation: exploring cognitive authority on the Internet", Reference Services Review, Vol. 30 No. 3, pp. 242-254, doi: 10.1108/ 00907320210435509 .

Gee, J.P. (1999), An Introduction to Discourse Analysis: Theory and Method, Routledge, London.

Goffman, E. (1983), “The interaction order”, American Sociological Review, Vol. 48 No. 1, pp. 1-17. 
$\mathrm{JD}$

78,7

60

Goodyear, V.A., Armour, K.M. and Wood, H. (2019), "Young people and their engagement with healthrelated social media: new perspectives", Sport, Education and Society, Vol. 24 No. 7, pp. 673-688, doi: 10.1080/13573322.2017.1423464.

Gorichanaz, T. (2017), "Understanding art-making as documentation", Art Documentation, Vol. 36 No. 2, pp. 191-203, doi: 10.1086/694239.

Gorichanaz, T. (2019), "Information creation and models of information behavior: grounding synthesis and further research", Journal of Librarianship and Information Science, Vol. 51 No. 4, pp. 998-1006, doi: 10.1177/0961000618769968.

Hargittai, E., Fullerton, L., Menchen-Trevino, E. and Thomas, K.Y. (2010), “Trust online: young adults' evaluation of web content", International Journal of Communication, Vol. 4, pp. 468-494.

Hicks, A. (2020), "Moving beyond the descriptive: the grounded theory of mitigating risk and the theorisation of information literacy", Journal of Documentation, Vol. 76 No. 1, pp. 126-144, doi: 10.1108/JD-07-2019-0126.

Hirvonen, N. and Palmgren-Neuvonen, L. (2019), "Cognitive authorities in health education classrooms: a nexus analysis on group-based learning tasks", Library and Information Science Research, Vol. 41 No. 3, 100964, doi: 10.1016/j.lisr.2019.100964.

Hirvonen, N., Tirroniemi, A. and Kortelainen, T. (2019), "The cognitive authority of user-generated health information in an online forum for girls and young women", Journal of Documentation, Vol. 75 No. 1, pp. 78-98, doi: 10.1108/JD-05-2018-0083.

Huang, G.C., Unger, J.B., Soto, D., Fujimoto, K., Pentz, M.A., Jordan-Marsh, M. and Valente, T.W. (2014), "Peer influences: the impact of online and offline friendship networks on adolescent smoking and alcohol use", Journal of Adolescent Health, Vol. 54 No. 5, pp. 508-514, doi: 10.1016/j. jadohealth.2013.07.001.

Hult, F.M. (2017), "Nexus analysis as scalar ethnography for educational linguistics", in Martin-Jones, M. and Martin, D. (Eds.), Researching Multilingualism: Critical and Ethnographic Perspectives, Routledge, London.

Hult, F.M. (2019), "Toward a unified theory of language development: the transdisciplinary nexus of cognitive and sociocultural perspectives on social activity", The Modern Language Journal, Vol. 103 No. S1, pp. 136-144, doi: 10.1111/modl.12527.

Huvila, I., Dougla, J., Gorichanaz, T., Koh, K. and Suorsa, A. (2020), "Conceptualizing and studying information creation: from production and processes to makers and making", Proceedings of the Association for Information Science and Technology, Vol. 57 No. e226, pp. 1-5, doi: 10.1002/ pra2.226.

Jones, R. (2020), "Mediated discourse analysis", in Adolphs, S. and Knight, D. (Eds), The Routledge Handbook of English Language and Digital Humanities, Routledge, London, pp. 202-219.

Kitzie, V. (2019), “That looks like me or something I can do': affordances and constraints in the online identity work of US LGBTQ+ millennials", Journal of the Association for Information Science and Technology, Vol. 70 No. 12, pp. 1340-1351, doi: 10.1002/asi.24217.

Koh, K. (2013), “Adolescents' information-creating behavior embedded in digital media practice using scratch", Journal of the American Society for Information Science and Technology, Vol. 64 No. 9, pp. 1826-1841, doi: 10.1002/asi.22878.

Koltay, T. (2017), "The bright side of information: ways of mitigating information overload", Journal of Documentation, Vol. 73 No. 4, pp. 767-775, doi: 10.1108/JD-09-2016-0107.

Kuure, L., Riekki, M. and Tumelius, R. (2018), "Nexus analysis in the study of the changing field of language learning, language pedagogy and language teacher education", AFinLA-E: Soveltavan Kielitieteen Tutkimuksia, Vol. 11, pp. 71-92, doi: 10.30660/afinla.69208.

Lane, P. (2014), "Nexus analysis", in Östman, J.-O. and Verschueren, J. (Eds), Handbook of Pragmatics, John Benjamins, Amsterdam.

Lankshear, C. and Knobel, M. (2011), New Literacies: Everyday Practices and Social Learning, 3rd ed., Open University Press, Maidenhead. 
Larsen, M.C. and Raudaskoski, P. (2018), "Nexus analysis as a framework for internet studies", in Hunsinger, J., Klastrup, L. and Allen, M. (Eds), Second International Handbook of Internet Research, Springer, Dordrecht, doi: 10.1007/978-94-024-1202-4_18-1.

Lincoln, Y.S.K. and Guba, E.G. (1985), Naturalistic Inquiry, Sage, Newbury Park, California.

Lloyd, A. (2010), "Framing information literacy as information practice: site ontology and practice theory”, Journal of Documentation, Vol. 66 No. 2, pp. 245-258, doi: 10.1108/00220411011023643.

Lloyd, A. (2011), "Trapped between a rock and a hard place: what counts as information literacy in the workplace and how is it conceptualized?", Library Trends, Vol. 60 No. 2, pp. 277-296, doi: 10.1353/lib.2011.0046.

Lloyd, A. (2017), "Information literacy and literacies of information: a mid-range theory and model", Journal of Information Literacy, Vol. 11 No. 1, pp. 91-105, doi: 10.11645/11.1.2185.

Ma, J. and Stahl, L. (2017), "A multimodal critical discourse analysis of anti-vaccination information on Facebook", Library and Information Science Research, Vol. 39 No. 4, pp. 303-310, doi: 10.1016/j. lisr.2017.11.005.

McKenzie, P.J. (2003), "Justifying cognitive authority decisions: discursive strategies of information seekers", The Library Quarterly: Information, Community, Policy, Vol. 73 No. 3, pp. 261-288.

McKenzie, P.J., Davies, E. and Williams, S. (2014), "Information creation and the ideological code of managerialism in the work of keeping track", Information Research, Vol. 19 No. 2, paper 614, available at: http://InformationR.net/ir/19-2/paper614.html (accessed 24 May 2021).

Multas, A.-M. and Hirvonen, N. (2019), "Employing nexus analysis in investigating information literacy", Proceedings of the Tenth International Conference on Conceptions of Library and Information Science, Ljubljana, June 16-19, 2019, Information Research, 24(4), paper colis1944, available at: http://nformationR.net/ir/24-4/colis/colis1944.html (accessed 30 April 2021).

Neal, D.M. and McKenzie, P.J. (2011), "Putting the pieces together: endometriosis blogs, cognitive authority, and collaborative information behaviour", Journal of the Medical Library Association, Vol. 99 No. 2, pp. 127-134, doi: 10.3163/1536-5050.99.2.004.

Nishida, K. (1958), Intelligibility and the Philosophy of Nothingness, Maruzen, Tokyo.

Norris, S. and Jones, R.H. (2005), "Discourse as action/discourse in action", in Norris, S. and Jones, R.H. (Eds), Discourse in Action: Introducing Mediated Discourse Analysis, Routledge, London, pp. 3-14.

Nygård, T., Hirvonen, N., Räisänen, S. and Korkeamäki, R.-L. (2020), “Ask your mother! Teachers' informational authority roles in information-seeking and evaluation tasks in health education lessons", Scandinavian Journal of Educational Research. doi: 10.1080/00313831.2020.1788145.

Nygren, T. and Guath, M. (2019), "Swedish teenagers' difficulties and abilities to determine digital news credibility”, Nordicom Review, Vol. 40 No. 1, pp. 23-42, 2019, doi: 10.2478/nor-2019-0002.

Oliphant, T. (2009), "I am making my decision on the basis of my experience': constructing authoritative knowledge about treatments for depression", Canadian Journal of Information and Library Science - Revue Canadienne Des Sciences de l'Information et de Bibliotheconomie, Vol. 33 Nos 3-4, pp. 215-232.

Olsson, M. (2010a), "The play's the thing: theater professionals make sense of Shakespeare”, Library and Information Science Research, Vol. 32 No. 4, pp. 272-280, doi: 10.1016/j.lisr.2010.07.009.

Olsson, M. (2010b), "All the world's a stage: making sense of Shakespeare", Proceedings of the American Society for Information Science and Technology, Vol. 47 No. 1, pp. 1-10.

Olsson, M. (2016), "Making sense to past. The embodied information practices of field archaeologists", Journal of Information Science, Vol. 42 No. 3, pp. 410-419.

Olsson, M. and Lloyd, A. (2017), "Being in place: embodied information practices", Proceedings of the Tenth International Conference on Conceptions of Library and Information Science, Uppsala, Sweden, June 27-29, 2016, Information Research, Vol. 22 No. 1, paper 1601, available at: http:// InformationR.net/ir/22-1/colis/colis1601.html (accessed 24 May 2021).

Video bloggers constructing cognitive authority 
$\mathrm{JD}$

78,7

62

O’Reilly, M. and Dogra, N. (2017), Interviewing Children and Young People for Research, SAGE Publications Ltd, London. doi: 10.4135/9781526419439.

Papen, U. (2013), "Conceptualising information literacy as social practice: a study of pregnant women's information practices", Information Research, Vol. 18 No. 2, available at: http:// informationr.net/ir/18-2/paper580.html\#.YBqic-gzY2w (accessed 30 April 2021).

Ping Helsinki (2020), "Case: \#faktaakoronasta - luotettavalla tiedolla koronavirusta vastaan", available at: https:/pinghelsinki.fi/case-faktaa-koronasta/ (accessed 30 April 2021).

Purdue, M. (2019), "Influencer, celebrity, journalist? Teens are turning to YouTube for news, survey shows", USA Today, 14 August 2019, available at: https:/eu.usatoday.com/story/tech/news/ 2019/08/13/youtube-influencers-teen-news-source-despite-being-called-unreliable/1992640001/ (accessed 3 February 2021).

Räisänen, S. (2015), "Changing literacy practices: a becoming of a new teacher agency", Acta Universitatis Ouluensis, E Scientiae Rerum Socialium, Vol. 15, University of Oulu, Oulu, available at: http://jultika.oulu.fi/files/isbn9789526208480.pdf (accessed 30 April 2021).

Rieh, S.Y. (2000), "Information quality and cognitive authority in the world wide web", Unpublished doctoral dissertation, Rutgers University, New Brunswick, New Jersey.

Rieh, S.Y. (2002), "Judgment of information quality and cognitive authority in the web", Journal of the American Society for Information Science and Technology, Vol. 53 No. 2, pp. 145-161.

Rieh, S.Y. (2010), "Credibility and cognitive authority of information”, in Bates, M. and Maack, M.N. (Eds), Encyclopedia of Library and Information Sciences, 3rd ed., Taylor and Francis Group, New York, pp. 1337-1344.

Rieh, S.Y., Jeon, G.Y., Yang, J.Y. and Lampe, C. (2014), “Audience-aware credibility: from understandin audience to establishing credible blogs", Proceedings of the International AAAI Conference on Web and Social Media, Vol. 8 No 1, pp. 436-445.

Rivano Eckerdal, J. (2011), "Young women choosing contraceptives: stories about information literacy practices related to evaluation and use of information sources", Dansk Biblioteksforskning, Vol. 7 Nos 2/3, pp. 19-31, doi: 10.7146/danbibfor.v7i2/3.97376.

Scollon, R. (2001), Mediated Discourse: The Nexus of Practice, Routledge, New York.

Scollon, R. and Scollon, S.W. (2004), Nexus Analysis: Discourse and the Emerging Internet, Routledge, London.

Scollon, S.W. and de Saint-Georges, I. (2011), "Mediated discourse analysis", in Gee, J.P. and Handford, M. (Eds), The Routledge Handbook of Discourse Analysis, Routledge, London, pp. 66-78.

Street, B. (2003), "What's new in new literacies studies? Critical approaches to literacy in theory and practice", Current Issues in Comparative Education, Vol. 5 No. 2, pp. 1-14.

Subramaniam, M., Taylor, N.G., St. Jean, B., Follman, R., Kodama, C. and Casciotti, D. (2015), “As simple as that?: tween credibility assessment in a complex online world", Journal of Documentation, Vol. 71 No. 3, pp. 550-571, doi: 10.1108/JD-03-2014-0049.

Swist, T., Collin, P., McCormack, J. and Third, A. (2015), Social Media and the Wellbeing of Children and Young People: A Literature Review, Commissioner for Children and Young People, Western Australia, Perth, Washington, available at: https:/www.westernsydney.edu.au/_data/assets/ pdf_file/0019/930502/Social_media_and_children_and_young_people.pdf (accessed 30 April 2021).

Talboom, S. and Pierson, J. (2014), "Providing trustworthy advice online: an exploratory study on the potential of discursive psychology in trust research", in Zhou, J., Gal-Oz, N., Zhang, J. and Gudes, E. (Eds), Trust Management VIII. IFIPTM 2014. IFIP Advances in Information and Communication Technology, Vol. 430, Springer, Berlin, Heidelberg, pp. 141-156. doi: 10.1007/9783-662-43813-8_10.

Trace, C.B. (2007), "Information creation and the notion of membership", Journal of Documentation, Vol. 63 No. 1, pp. 142-164, doi: 10.1108/00220410710723920. 
Tuominen, K., Talja, S. and Savolainen, R. (2002), "Discourse, cognition, and reality: toward a social constructionist metatheory for library and information science", in Bruce, H., Fidel, R., Ingwersen, P. and Vakkari, P. (Eds), Emerging frameworks and methods: CoLIS 4. Proceedings of the Fourth International Conference on Conceptions of Library and Information Science, Libraries Unlimited, Greenwood Village, Colorado, pp. 271-283.

UNESCO (2021), "By youth, with youth, for youth", available at: https://en.unesco.org/youth (accessed 22 April 2021).

van Kessel, P., Toor, S. and Smith, A. (2019), A Week in the Life of Popular YouTube Channels,

Video bloggers constructing cognitive authority Pew Research Center, available at: https://www.pewresearch.org/internet/2019/07/25/a-week-inthe-life-of-popular-youtube-channels/ (accessed 3 February 2021).

Vaterlaus, J.M., Patten, E.V., Roche, C. and Young, J.A. (2014), “\#Gettinghealthy: the perceived influence of social media on young adult health behaviors", Computers in Human Behavior, Vol. 45, pp. 151-157, doi: 10.1016/j.chb.2014.12.013.

Wartella, E., Rideout, V., Montague, H., Beaudoin-Ryan, L. and Lauricella, A. (2016), "Teens, health and technology: a national survey", Media and Communication, Vol. 4 No. 3, pp. 13-23, doi: 10.17645/mac.v4i3.515.

Whitworth, A. (2014), Radical Information Literacy: Reclaiming the Political Heart of the IL Movement, Chandos Publishing, Oxford.

Wilson, P. (1983), Second-hand Knowledge: An Inquiry into Cognitive Authority, Greewood Press, Westpot, Connecticut.

Wilson, P. (1991), "Bibliographic instruction and cognitive authority", Library Trends, Vol. 39 No. 3, pp. 259-270.

Wohlwend, K. (2020), Literacies that Move and Matter, Routledge, Taylor \& Francis Group, New York and London.

YouTube (2021), "YouTube About", available at: https://www.youtube.com/intl/en/about/press/ (accessed 24 May 2021). 


\section{Appendix}

78,7

\begin{tabular}{|c|c|c|}
\hline NA concept & Guiding questions & $\begin{array}{l}\text { Cues for the analysis; } \\
\text { Talk or visual presentation of }\end{array}$ \\
\hline $\begin{array}{l}\text { Discourses in } \\
\text { place }\end{array}$ & $\begin{array}{l}\text { How are mediational means used in the } \\
\text { social action? } \\
\text { What kinds of discourses are present in the } \\
\text { social action? What is talked about, and } \\
\text { how? } \\
\text { What kinds of information sources are } \\
\text { deemed trustworthy and/or competent? }\end{array}$ & $\begin{array}{l}\text { The chosen information-seeking methods, the } \\
\text { used technologies and tools } \\
\text { The used information sources }\end{array}$ \\
\hline $\begin{array}{l}\text { Interaction } \\
\text { order }\end{array}$ & $\begin{array}{l}\text { What kinds of roles and role expectations } \\
\text { do the participants have? } \\
\text { How does the interaction play out between } \\
\text { the video blogger and her audience or the } \\
\text { researcher? } \\
\text { What kinds of power relations or mutual } \\
\text { histories are present in the social action? }\end{array}$ & $\begin{array}{l}\text { The information that is presented to the } \\
\text { audience and researcher } \\
\text { The norms and attitudes that are guided by } \\
\text { peer groups or other communities }\end{array}$ \\
\hline $\begin{array}{l}\text { Historical } \\
\text { body }\end{array}$ & $\begin{array}{l}\text { What kinds of information practices emerge } \\
\text { in the social action? } \\
\text { What kinds of activities are related to } \\
\text { information-seeking and evaluating } \\
\text { situations? } \\
\text { What prior knowledge and experiences are } \\
\text { brought to the scene? How habitual is this } \\
\text { action for the participants? }\end{array}$ & $\begin{array}{l}\text { The learned practices, experiences and } \\
\text { motives regarding information-seeking and } \\
\text { credibility assessment } \\
\text { Authority statements about information } \\
\text { sources } \\
\text { The differences between talk and actions }\end{array}$ \\
\hline
\end{tabular}

\section{Corresponding author}

Anna-Maija Multas can be contacted at: anna-maija.multas@oulu.fi

For instructions on how to order reprints of this article, please visit our website: 